\title{
OBITUARY
}

\section{DR. ERNEST E. MADDOX}

By the death of Dr. Ernest Fdmund Maddox which occurred on November 4, at his home in Bournemouth, British Ophthalmology has lost one of its most distinguished ornaments and ablest exponents.

Dr. Maddox, who was educated at Mill Hill School and the University of Edinburgh, was the son of Mr. J. F. Maddox, of Shipton, Oxfordshire, and graduated M.B., C.M. in 1882, M.D. in 1889, and F.R.C.S.E. in 1894.

As a student he distinguished himself by gaining the "first medal of his year in physiology," and the "Primary Fellowship of the College of Surgeons of England," and after qualifying, the Syme Surgical Fellowship for his work on the "Accommodation and Convergence of the Eyes." These successes were but a faint indication of the excellent work and distinguished career that were to follow.

His early professional life (for he decided to devote himself to eyes) was spent in Edinburgh, where he practised for about ten years during which time after being resident physician he held the appointments of Assistant Ophthalmic Surgeon and University Ophthalmoscopic Tutor. During these years he was associated with Argyll Robertson and Berry, and not only increased his reputation as a teacher, but also as an operator.

Atter a long period of ill-health he left Edinburgh, and owing to his association with the late Dr. Roberts-Thomson of Bournemouth, he was given the appointment of Ophthalmic Surgeon to the Royal Victoria Hospital, Bournemouth, and later that of the Royal Boscombe and West Hants. Hospital, which appointments he held for many years until he retired from hospital work altogether.

The greater part of his brilliant work was done in that town, where he laboured until the time of his death, unceasingly, for the good and welfare of his patients.

Dr. Maddox wrote extensively, and all his communications were marked by outstanding merit, and bore the stamp of a master mind.

As an author (in the writer's opinion) he excelled in originality, clarity of thought and expression, and he had the ability of making deep and obscure things clear, even to the uninitiated.

While he could teach well it was not his strong point; he was primarily and essentially an investigator and was constantly in pursuit of new and fresh methods in connection with his work. Anything original delighted him immensely and he was most punctilious as to giving honour where that was due. The writer well remembers his delight on the discovery that in the pendulum 
lay the geometrical and mathematical explanation of the fact that two crossed cylinders make a sphere spherical.

He was so well informed himself that he could not tolerate ignorance in those around him, and to discuss anything with him one had to be at home in all the essentials and what was to be be known in order to start.

He was an excellent critic because he was so well informed and his judgment was always good and just and his advice worth having, and it was always given sympathetically. All his writings were marked by thoroughness which was the outcome of a complete mastery of the subject. For his book, "Tests and Studies of the Ocular Muscles," the writer knows that he read practically all the original work on the brain that was available at the time. The mutual pleasure derived from the study of Bruce's work on the mid and hind brain preliminary to a contemplated revision of his book is still very vivid in the writer's recollection. Of his outstanding works may be mentioned his book on the "Clinical Use of Prisms and the Decentering of Lenses," which went into the fifth edition, and is a work of reference. The originality of his teaching could easily be seen in this book where he drew attention to the treatment of the anomalies of the extrinsic muscles of the eye. His ocular demonstration of points made through the medium of geometrical methods were most ingenious and all he advocated there has been most generally accepted. His Tests and Studies of the Ocular Muscles was edited both in America and Germany and was a levelheaded presentation of the subject; his "Golden Rules of Refraction" (an exceedingly clever little book) went to a third edition. He was an excellent refractionist and was one, if not the first, to use the Jackson Cross Cylinder in this country, as a quantitative test for astigmatism. He took the greatest pains with his refraction work and it was rarely one could trip him up in an axis deter. mination. Among his other contributions of note early in his career was a paper on the Relation between the Convergence and Accommodation of the Eyes published in the Journal of Anatomy and Physiology; his article on Refraction in the Encyclopaedia Medica, and one on the Ocular Muscles in Latham and English's "System of Treatment." He was the greatest living authority on the Phorias; his contribution in the discussion at the Ophthalmological Society and also his Doyne lecture in 1921 (before the Oxford Ophthalmological Congress) on Heterophoria, were masterly.

He was a student all his life, and the above by no means exhausts the valuable contributions that came from his pen. There were few meetings of any standing at which he was not to be seen contributing papers or taking some part in the procedure, or showing instruments or apparatus, for he was an inventor of no mean order; 
in this connection one can mention the "Maddox rod," his cylinder axis finder, his double prism, eye heaters, cataract needles, wing test, his method of photographing the corneal reflex in squint; his " $V$ " test for astigmatism, and later his cheiroscope, a device whereby the eye of a squinting child (amblyopic from disuse) is educated by a method which excites the child's own interest. The patient being caused to make a conscious effort with the hand while the brain is unconsciously educated to perceive the image thrown on the retina by means of the effort. All his things were good and useful. $\mathrm{He}$ was a most brilliant operator, and in the different operations for cataract he was probably seen at his best. He was especially fond of extraction in the capsule and his results in this operation were phenomenally good. His delicacy of touch and his capability of rising to any operative emergency showed what a great exponent he was of his craft. This skill he maintained to the end.

$\mathrm{He}$ was interested in everything scientific and one of his latest discoveries published in the Brit. Jl. of Ophthal. in March, 1933, was the effect of high frequency currents in lowering the tension of hyper-tense eyes and suitable cases of chronic glaucoma.

He was fond of astronomy and his interest in this department of science led to the invention of his "starfinder," a useful little appliance for the teaching of astronomy, and by which the merest tyro could find any particular constellation or star. All his equipment was marked by originality and ingenuity and his consulting room was a veritable treasure house of knowledge. One always learned something from a visit to him.

A few hours before he entered the nursing home he was more concerned with the removal of an eye by some new method that he had adopted than the ordeal he had so soon to undergo. $\mathrm{He}$ worked to the last hour. His qualities were so many and admirable that it is difficult to enumerate and assess them.

He was not only well known in this country but his position in Ophthalmology was widely recognised and his reputation was world-wide. One of the safest testimonies was the frequency with which his counsel and opinion was sought by Ophthalmologists far and near. It is safe to say, and the writer speaks from experience, that there is no one whose memory will be held with more regard and esteem by the Ophthalmological branch of the profession all over the world than that of Maddox.

$\mathrm{He}$ was an inveterate worker and his work was not done so much for himself as for Ophthalmology and British Ophthalmology in particular, and both owe a deep indebtedness to him.

His work towards the end was largely concerned with the orthoptic training of squint in children. Its commencement here, in this country, and the Clinics which are now established for this work in different parts of the country owe their origin, primarily, to him. 
Among his distinguished honours one may mention the "Middlemore Prize of the British Medical Association," given for the best contributions to Ophthalmology during the three years ending 1899; this he obtained for his Tests and Studies of the Ocular Muscles to which we have already alluded; the "Doyne Memorial Medal of the Oxford Ophthalmological Congress" in 1921, for his contributions on Heterophoria.

He was at different times a member of the Council and VicePresident of the Ophthalmological Society of the United Kingdom, and President of the Ophthalmic Section of the British Medical Association, at its meeting held in Eastbourne in 1931, and was to have been President at the Meeting in Bournemouth, in 1934. He was a corresponding member of the "Société française d'Ophtalmologie."

Dr. Maddox married, in 1893, Grace Rivers, daughter of Alexander Monteath, C.S.I., of the Broich and Duchally, Perthshire, by whom he had a large family, and to whom the sympathy of Ophthalmologists all over the World is extended.

J. BURDON COOPER.

\section{T. H. BICKERTON}

I $\mathrm{T}$ is with great regret that we announce the death on November 23, 1933, of Mr. Thomas Herbert Bickerton, the doyen of ophthalmology in the North of England. His whole working life was passed in Liverpool, of which great city he was a leading citizen; and although he retired from practice some years ago and had settled in the South of England, he returned to his native place about three years ago after the death of his wife, and spent the last years of his life in his beloved Liverpool.

Mr. Bickerton was born in 1857. His father, Thomas Bickerton, was a Liverpool surgeon, who practised in diseases of the nose and throat as well as in ophthalmology. He died while the subject of our memoir was in his teens. Educated at the Liverpool Institute and Royal Infirmary, the son completed his medical education at the London Hospital and took the M.R.C.S.Eng. in 1879. After having held the post of House Surgeon at the Liverpool Royal Infirmary, he became clinical assistant at Moorfields and later took a postgraduate course at Vienna. He was thus peculiarly well fitted to specialise in ophthalmology on his return to England. He joined Mr. Shadford Walker (first as assistant and later as partner), who at that time was the senior ophthalmic surgeon in Liverpool. In 1886 he was elected ophthalmic surgeon to the Liverpool Royal Infirmary, of which institution he was President in 1923. But besides his work in Liverpool itself he was connected with numerous other Hospitals in a consulting capacity. He conducted a very large practice and was a popular and highly respected surgeon. 